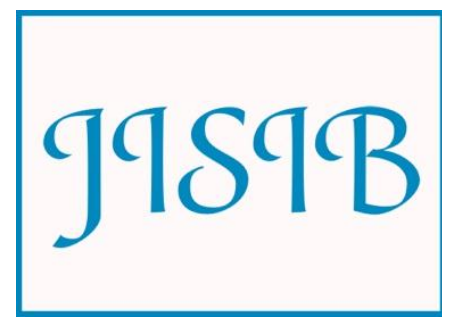

Available for free online at https://ojs.hh.se/

Journal of Intelligence Studies in Business 1 (2013) 15-30

\title{
The Relationship between Strategic Planning and Company Performance - A Chinese perspective
}

\author{
Per Jenster* and Klaus Solberg Søilen** \\ *Nordic International Management Institute (NIMI), China \\ per.jenster@nimichina.com \\ **Halmstad University, Sweden \\ klasol@hh.se
}

Received February 10 2012, Revised form March 3, accepted February 132013

\begin{abstract}
What is the relationship between Strategic Planning and Company Performances in Chinese companies? Is there a correlation between Company Performance and the Strategies adopted by these companies, using the Miles and Snow model for Aggressiveness Strategies? And is it possible to say something more about what kind of Strategic Planning gives better Company Performances? We wanted to separate here between the Planning which is related to what is called Competitive Intelligence and other activities related to Planning. The Idea was to be able to say something about the importance of Competitive Intelligence. We also wanted to use more extensive statistical analysis with more variables in light of the criticisms that has been raised about the methodology of previous studies. We found that better planning had a positive effect on a number of key business performance measures. We found that there was indeed a distinction between the different strategies selected and Company Performance. The strategy type named Reactors performed systematically less well than companies who choose one of the other strategies. Moreover we found that there were differences between different planning activities and Company Performance and that activities related to Competitive Intelligence were on the average more important for Company Performance than other Planning activities.
\end{abstract}

KEYWORDS: Strategic Planning, Company Performances, Competitive Intelligence

\section{Introduction}

There are seemingly no ends of studies on Strategic Planning and Company Analysis. Why then another one? For one thing the problem has not been solved satisfactory yet. Previous studies have shown quite different results and their methodologies have been seriously questioned. Besides that all studies are to our knowledge on Western companies. We wanted to see the effects on Chinese companies to be able to make some sort of comparison. We also wanted to focus on a special type of Long Range planning, 
namely the Competitive Intelligence (CI) function. Is the CI function more important for Company Performance than other types of Strategic Planning? Furthermore, is it possible to see what kind of strategies companies that perform better have chosen? To find out we needed to select a well acknowledged Strategic model and test it against the correlation between Strategic Planning and Company Performance. This would already imply a more advanced statistical analysis. Much criticism has been directed to the methodology of these studies. We found that the number of variables tested in previous studies were quite limited in numbers. This is an issue because Company Performance, but first of all Strategic Planning encompasses such a wide range of activities. The variables testing Company Performance are less controversial and often the same in different studies; sales growth, return on capital, cost of production, quality of products, innovativeness, profits etc. The variables used for Strategic
Planning are not only potentially more numerous and therefore less obvious, but often not shown in the actual studies. The multiple regression analysis tables are often just summaries of the actual research where strategic planning is reduced to one variable. If the reader of these studies is to be critical he or she needs to see all of the calculations however cumbersome, so we added appendixes AG.

Brody has shown that there is often a misconception as to what exactly $\mathrm{CI}$ is. $\mathrm{CI}$ is the practice of defining, gathering, analyzing and distributing need-to-know information to the organization's decision makers. As such it is a vital part of Strategic Planning. Even though its process is simple, following the so called Intelligence Cycle, each stage in the cycle is relatively complex. This means that any study that wants to capture its significance needs to test a large number of different variables. The logic for the study can be expressed as follows:

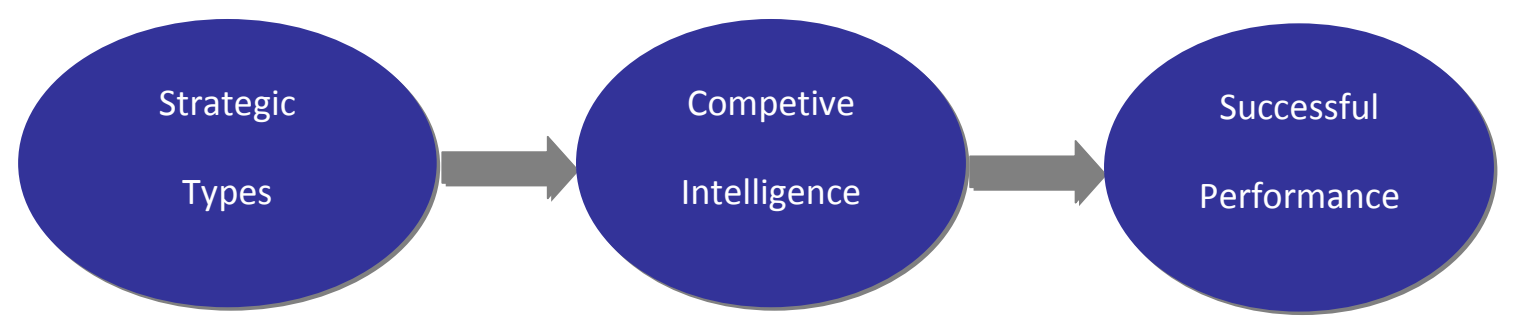

Figure 1: A model for including Competitive Intelligence in the study of the correlation between Strategy Types and Successful Performance

Each company chooses or can be defined according to at least one strategy. After all, if the company does not have a strategy that can be defined as a strategy too. The chosen strategy again defines the company's competitive intelligence activities, explicitly or implicitly, along the same logic. The result of these activities will again and to a large extent define the relative success of the company, or its performance.

\section{Literature review}

There is much empirical research on Planning and Performance in general, but no major research on CI and performance. Tianjiao (2008) looks at the effects of proactive scanning on performance. Others have studied the reverse relationship, how $\mathrm{CI}$ is a precedent to marketing strategy formulation (Dishman and Calof, 2008).
Is there reason to believe that Chinese firms should be different, or that the dynamic Chinese business environment might call for different approaches? Or do Chinese companies react and function in much the same way as Western companies when it comes to Strategic Planning and Company Performance? These were the questions and considerations which started this research.

In the general literature it is a problem that results from research performed on Strategic Planning and Company Performance differs greatly, even over time, and so much that it has spurred a debate about the rigor and value of different methods used in these studies (e.g. Ruud, Greenley, Beatson and Lings 2008). Along this line, Rhyme (1986), Miller 
and Cradinal (1994), Brews and Hunt (1999), Andersen (2000), Delmar and Share (2003) have found a positive association between planning and performance. Shrader et al. (1984) and Pearce et al. (1987) found that there is no such relationship. Falshaw, Glaister and Tatoglu (2006) found there was no such relationship among UK companies. Boyd (1991), Greenley (1994) and Hahn and Powers ( 1999) has shown how this has hindered the progress of research for this problem. Schwenk and Shrader (1993), Leilich (1993) and Leilich and Marcus (2006) have suggested that other factors will impact on the relationship between strategic planning and performance.

Strategic Planning is an old topic of interest in Management Science. Early research on strategic planning has been carried out by Steiner (1963, 1979), Learned et al. (1965), Ansoff (1965), Steiner and Cannon (1966), Ackoff (1970), Mintzberg (1979), Ansoff et al. (1976), Armstrong (1982), Pearce et al. (1987), Ansoff (1991), Miller \& Cardinal (1994), Mintzberg and Lampel (1999) and Falshaw and Tatoglu, (2006). The findings of this research have also been inconclusive, as suggested by the book by Mintzberg "The Rise and Fall of Strategic Planning" (1994). Again critique has been raised against the rigor in the methodology used (Greenley, 1986 and 1994). Greenley (1994) found that a number of differences were found among the methodologies of the studies so that each study is deemed limited. Consequently, the results cannot be legitimately combined, and it cannot be concluded that an association is evident (Greenley, 1994). Mintzberg has also described other problems areas;

\section{The empirical study}

To simplify all the different strategy types possible then we used the above discussed model presented by Miles and Snow. It describes four main types of the adhoc way of forming strategy in state departments (1985), and the difficulties that Strategy imposes on Entrepreneurial firms (1982).

The idea of trying to identify a finite number of important strategic choices for any organization starts with Chandler (1962) and Child (1972). A major contribution is made by Miles and Snow (1978), who develop the theory of Strategic Equifinality, the idea that within a particular industry or environment there are a finite number of ways to succeed. This research again inspired Porter's (1980) generic strategies, of cost leadership, differentialization and focus, developed further in Porter (1987). Since then research on Miles and Snow (1978) have been carried out by Hambrick (1983 \& 2003), Jenster (1985), McDaniel and Kolari (1987), Ruekert and Walker (1987), McKee, Varadarajan, and Pride (1989), Conant, Mokwa, and Varadarajan, (1990), Shorel and Zajac (1990), Matsuno \& Mentzer (2000), Desarbo, Benedetto, Song and Sinha, (2004) AragonSanchez \& Sanchez-Marin (2005), and Pleshko \& Nickerson, (2006). Parnell \& Wright (1993) confirm earlier results where Reactors are outperformed by Prospectors, Analyzers and Defenders. Prospectors tend to have more market research competence, key personal involvement, innovativeness also greater implementation planning (Veliyath \& Shortell, 1993). Others have claimed that Prospectors outperform other types in dynamic markets (Shorel and Zajac, 1990). Hambrick (1981), Segev (1987) and James and Hatten (1995) have confirmed the value of the Miles and Snow Typology.

strategies; Defenders (A), Prospectors (), Analyzers (C) and Reactors (D). They are explained in more detail below. 
A

Type A firms are organizations that have narrow productmarket domain. Top managers in this type of organization are highly expert in their organization's limited area of operation but do not tend to search outside of their domains for new opportunities. As a result of this narrow focus, these organizations seldom need to make major adjustments in their technology, structure, or methods of operation. Instead, they devote primary attention to improving efficiency of their existing operations.

C

Type $C$ firms are organizations that operate in two types of product-market domains, one relatively stable, the other changing. In their stable areas, these organizations operate routinely and efficiently through use of formalized structures and processes. In their more turbulent areas, top managers watch their competitors closely for new ideas, and then they rapidly adopt those that appear to the most promising.
Type B firms are organizations that almost continually search for market opportunities, and they regularly experiment with potential responses to emerging environmental trends. Thus, these organizations often are the creators of change and uncertainty to which their competitors must respond. However, because of their strong concern for product and market innovation, these organizations usually are not completely efficient.

D

Type D firms are organizations in which top managers frequently perceive change and uncertainty occurring in their organizational environments but are unable to respond effectively. Because this type of organization lacks a consistent strategy/structure relationship, it seldom makes adjustment of any sort until forced to do so by environmental pressures.

\section{Figure 2: The Miles and Snow (1978) model for Aggressive Strategies in Business}

To be able to test Chinese companies per se we ventures, privately owned, state owned etc. selected a wide variety of different companies; joint

\begin{tabular}{|l|l|l|}
\hline Category & Frequency & Percent \\
\hline Joint-venture & 21 & 8.7 \\
\hline Private-Owned Enterprise & 69 & 28.6 \\
\hline Shareholding & 53 & 22 \\
\hline State Owned Enterprises & 27 & 11.2 \\
\hline Wholly Foreign-owned & 67 & 27.8 \\
\hline Others & 4 & 1.7 \\
\hline Sum & 241 & $100 \%$ \\
\hline
\end{tabular}

Table 1: Types of companies included in the study

We also made sure that we had companies representing all of the four different strategy types. 


\begin{tabular}{|l|l|l|}
\hline Type & Frequency & Percent \\
\hline A & 61 & 25.3 \\
\hline B & 45 & 18.7 \\
\hline C & 90 & 37.3 \\
\hline D & 44 & 18.3 \\
\hline Undefined & 1 & 0,6 \\
\hline Sum & 240 & $100 \%$ \\
\hline
\end{tabular}

Table 2: Number of companies across the different strategy types

Next we set up a number of hypotheses or questions to be answered. The first was to confirm or reject previous research in the field by repeating the standard hypothesis used in other studies on Strategic Planning and Company Performance. The only difference would be that our general hypothesis tested for Chinese companies operating in china, not for Western companies.

H1. There is a strong, positive correlation between the level of formal strategic planning and the degree of satisfaction of performance

We then wanted to find out whether or not Companies perform differently depending on their different Aggressiveness strategies. The limited strategies selected are those of Miles and Snow (1978); divided into Reactors (no proactive strategy), Prospectors, (have programs to expand into new markets and stimulate new opportunities), Analyzers (are in between the defender and prospector), and Defenders (maintain a secure and relatively stable market). These strategies were tested across 13 selected Performance criteria.

H2. Companies perform differently depending on their different Aggressiveness strategies.

More importantly we wanted to see if certain planning practices have a more significant effect on the performance model. It would be possible to see this directly by comparing the results from the statistic analysis.
H3. Certain planning practices have a more significant effect on the performance model

In a continuation of this we wanted to be able to say something about the correlation of those planning practices which may be defined as a Competitive Intelligence. To distinguish CI planning practices from other activities we divided all our questions into three types, $\mathrm{X}, \mathrm{XX}$ and 0 . Where $\mathrm{O}$ means there is no special relationship with CI activities, $\mathrm{X}$ means there is a relationship and $\mathrm{XX}$ means there is a strong relationship. These assessments were made based on the definition of what $\mathrm{CI}$ is. Based on our findings we would be able to answer the next hypotheses:

H4. Competitive Intelligence practices have a significant effect on performance.

At the end we also wanted to be able to say something about the importance of Competitive Intelligence practices as opposed to other strategic planning processes or variables.

H5. Competitive Intelligence practices have a higher significant effect on performance than other planning activities

Our hypotheses were subjected to an empirical investigation. 241 valid questionnaires were collected among students attending an MBA executive program representing Chinese medium and large size companies. The 13 performance criteria were selected (Appendix A). 33 questions were asked on Strategic Planning (Appendix B). 
Two questions were later redrawn on suspicions of misunderstanding on the part of the subjects. A Likert Scale from 1-7 was used to indicate the degree of response, where 1 was very poor and 7 very good. The questions were asked about their recent experience as to avoid any differences in what experiences were measured and to make sure the experience was up to date. This was particularly important in our case as the Chinese companies have gone through and are going through periods of great change, also in terms of strategic planning and company performance. The companies were largely

\section{Results and Analysis}

Overall response rate was $100 \%$. The sample was tested for non-response biases and differences between those who had returned the questionnaire from the major industrial areas of China but spread about the whole country. The actual interviews were done in the form of questionnaires in connections with lectures. To obtain the maximum of objectivity in the answers all participants were able to answer anonymously. The questionnaires were pretested by 25 students or about $10 \%$ of the actual sample. This allowed for some alterations of the actual questions. A t-test was performed to assess whether the means of two groups performance and strategy types were statistically different from each other.

early and those who were late. No significant difference was found. The results across the four strategy types for the 13 measures used were as follows:

\begin{tabular}{|c|c|c|c|c|c|c|c|c|c|c|c|c|c|}
\hline & a & b & c & d & e & $f$ & g & h & i & j & $k$ & I & $m$ \\
\hline А Туре & 5.28 & 5.28 & 4.87 & 4.48 & 4.97 & 5.34 & 4.64 & 5.13 & 4.89 & 4.92 & 5.03 & 4.95 & 5.25 \\
\hline В Type & 5.53 & 5.47 & 5.18 & 5.07 & 4.98 & 5.42 & 5.36 & 5.38 & 4.96 & 5.13 & 5.29 & 5.09 & 5.39 \\
\hline C Type & 5.42 & 5.21 & 5.10 & 4.34 & 4.92 & 5.14 & 4.80 & 5.12 & 4.83 & 5.22 & 5.30 & 4.94 & 5.27 \\
\hline D Type & 4.61 & 4.43 & 4.41 & 3.95 & 3.80 & 4.57 & 4.14 & 4.34 & 4.07 & 4.41 & 5.05 & 4.18 & 4.61 \\
\hline
\end{tabular}

\section{Table 3: Average Score}

We see that $\mathrm{D}$ type has the lowest average score of all the performance criteria (except $\mathrm{k}$-Social responsibility). Does that mean $\mathrm{D}$ type of companies have lower performance than the other three types of companies? To find out more precise we did a T-Test. For the t-test, if the p-value associated with the t-test is small (usually set at $\mathrm{p}<$ 0.05 ), there is evidence that the mean is different from the hypothesized value (which is set to be 0 ).
If the p-value associated with the $t$-test is not small $(p>0.05)$, then the null hypothesis is not rejected, and we can conclude that the mean is not different from the hypothesized value. We're run pair wise $t-$ test between the four types: A vs. B, A vs. C, A vs. D, B vs. C, B vs. D, C vs. D, on each of the 13 performance criteria: a-m. The p-values showed whether or not the four types are significantly different from each other. 


\begin{tabular}{|c|r|r|r|r|r|r|}
\hline P Value & A vs. B & A vs. C & A vs. D & B vs. C & B vs. D & C vs. D \\
\hline $\mathbf{a}$ & 0.3982 & 0.6305 & 0.0005 & 0.6373 & 0.0152 & 0.0006 \\
\hline $\mathbf{b}$ & 0.7926 & 0.9353 & 0.0296 & 0.7223 & 0.0256 & 0.0208 \\
\hline $\mathbf{c}$ & 0.7772 & 0.4313 & 0.0044 & 0.685 & 0.0044 & $<.0001$ \\
\hline $\mathbf{d}$ & 0.7643 & 0.8101 & 0.0188 & 0.9166 & 0.059 & 0.018 \\
\hline $\mathbf{~}$ & 0.2362 & 0.5334 & 0.0336 & 0.0612 & 0.384 & 0.0035 \\
\hline $\mathbf{f}$ & 0.2606 & 0.1068 & 0.7348 & 0.8239 & 0.1731 & 0.0655 \\
\hline $\mathbf{g}$ & 0.3678 & 0.3823 & 0.7442 & 0.8486 & 0.254 & 0.2507 \\
\hline $\mathbf{h}$ & 0.9769 & 0.2931 & 0.276 & 0.3546 & 0.3016 & 0.0308 \\
\hline $\mathbf{i}$ & 0.6037 & 0.0409 & 0.5392 & 0.1966 & 0.9261 & 0.2415 \\
\hline $\mathbf{j}$ & 0.4556 & 0.1941 & 0.0526 & 0.7174 & 0.0136 & 0.0008 \\
\hline $\mathbf{k}$ & 0.4329 & 0.1171 & 0.5109 & 0.5759 & 0.9089 & 0.4904 \\
\hline $\mathbf{I}$ & 0.8485 & 0.4786 & 0.1993 & 0.6636 & 0.174 & 0.0397 \\
\hline $\mathbf{m}$ & 0.4013 & 0.2166 & 0.0795 & 0.8627 & 0.0193 & 0.0021 \\
\hline
\end{tabular}

Table 4: The t-test

We found here that Type A and Type B have same means on each of the 13 performance criteria. Type $\mathrm{B}$ and Type $\mathrm{C}$ have same means on each of the 13 performance criteria. Type $\mathrm{A}$ and Type $\mathrm{C}$ have same means on most of the 13 performance criteria, except i- Ability to attract, develop and keep talented manpower. Type $\mathrm{A}$ and Type $\mathrm{D}$ have same means on performance criteria $\mathrm{f}-\mathrm{m}$. Type $\mathrm{B}$ and Type D have same means on performance criteria $\mathrm{d}-\mathrm{I}, \mathrm{k}, \mathrm{l}$. Type $\mathrm{C}$ and Type D have same means on performance criteria $\mathrm{f}, \mathrm{g}, \mathrm{i}, \mathrm{k}$. Thus we conclude that Type A, B and C do not have much difference from each other on the 13 performance criteria. More interestingly we conclude that Type D has a difference from the other three types on the performance criteria, which are lower than others. Thus we confirm the second hypothesis:

H2. Companies perform differently depending on their different Aggressiveness strategies.
To solve the first hypothesis we use a Two -Way Analysis of Variance, using General Linear Model (GLM). GLM allows us to analyze categorical variables as well as numerical variables in the same model. In the model we use each performance criterion (a-m) as the dependent variable, all the planning practice (Q1-Q33) and Q36 (strategy types $\mathrm{A}, \mathrm{B}, \mathrm{C}, \mathrm{D})$, as the independent variables to do General Linear Model analysis. Then we find out if the planning practice and different strategy types both have an effect on the company performance. The $\mathrm{P}$ value of the model shows if the model is significantly valid. It also shows the significant effect of the independent variables contributing to the model.

As an example for the first Company Performance criteria (Sales growth for the past 5 years) we get the following formula:
Formula 1: The model

$$
\begin{aligned}
& \mathrm{a}=\beta_{0}+\beta_{1} \mathrm{Q} 1+\beta_{2} \mathrm{Q} 36 \\
& \Rightarrow \\
& \mathrm{a}=\beta_{0}+\beta_{1} \mathrm{Q} 1+\phi_{1} \mathrm{~A}+\phi_{2} \mathrm{~B}+\phi_{3} \mathrm{C}+\phi_{4} \mathrm{D}
\end{aligned}
$$

In this case " $\mathrm{a}$ " is the dependent variable. Q1-Q33 \& Q36 (A, B, C, D) are the independent variables. We define the total effect of A, B, C and D, to see if the different strategy types of the companies matters in the company performances. 


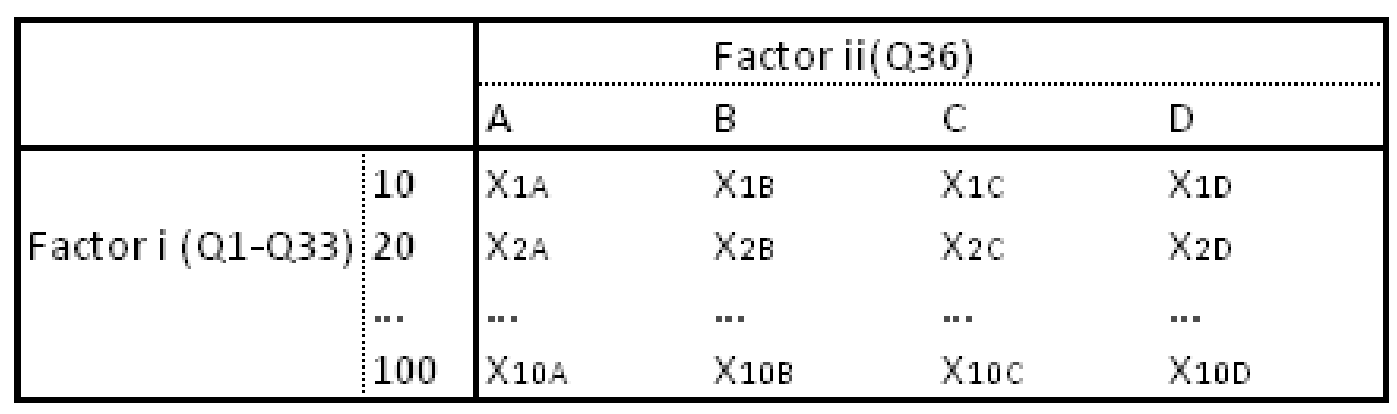

Table 5: Factor ii Analysis

We list some key indicators of the analysis. Since our sample is big, the $\mathrm{R}$ square will not be significant. We mainly looked into the $\mathrm{P}$ value, which shows the significant effect of the model and the variables.

For the Model:

$\mathrm{P}<=0.05-$ The effect of the model is valid.
P>0.05 - The effect of the model is NOT significantly valid.

For the Variables:

$\mathrm{P}<=0.05-$ The effect of the variable is significant or the coefficient is not zero.

$\mathrm{P}>0.05$ - The effect of the model variable is NOT significant or it's very probable that the coefficient is zero.

\begin{tabular}{|c|c|c|c|c|c|c|c|c|c|c|c|c|c|c|c|c|c|c|c|c|c|}
\hline Model & $Y$ & Model & $Y$ & Model & $\mathrm{N}$ & Model & $\gamma$ & Model & $Y$ & Model & $\mathrm{N}$ & Model & $Y$ & Model & $\gamma$ & Model & Y & Model & $\gamma$ & Model & $\mathrm{N}$ \\
\hline Q1 & $\mathrm{N}$ & Q2 & $Y$ & Q3 & $\mathrm{N}$ & $Q 4$ & $\gamma$ & 0.5 & $Y$ & Q6 & $N$ & $Q 7$ & $\gamma$ & Q8 & $\mathrm{N}$ & Q9 & $\mathrm{N}$ & Q10 & N & Q.11 & $N$ \\
\hline Q36 & $Y$ & Q36 & $\mathrm{N}$ & Q36 & $\gamma$ & Q36 & $Y$ & Q36 & $\mathrm{N}$ & Q36 & $\gamma$ & Q36 & $\mathrm{N}$ & Q36 & $Y$ & Q36 & $\gamma$ & Q36 & $Y$ & Q36 & $Y$ \\
\hline Model & $N$ & Model & $N$ & Model & $Y$ & Model & $Y$ & Model & $Y$ & Model & $Y$ & Model & $Y$ & Model & Y & Model & $\gamma$ & Model & $\gamma$ & Model & $Y$ \\
\hline$Q 12$ & $N$ & $Q 13$ & $N$ & Q.14 & $\gamma$ & $Q 15$ & $\gamma$ & $Q 16$ & $Y$ & Q17 & $Y$ & Q18 & $Y$ & Q19 & $\gamma$ & $Q 20$ & $\gamma$ & 0.21 & $\gamma$ & 0.22 & $N$ \\
\hline Q36 & $Y$ & Q36 & $Y$ & $Q 36$ & $Y$ & Q36 & $N$ & Q36 & $N$ & Q36 & $\mathrm{N}$ & Q36 & $N$ & Q36 & $\mathrm{N}$ & Q36 & $\gamma$ & Q36 & $\mathrm{N}$ & Q36 & $\mathrm{N}$ \\
\hline Model & $\gamma$ & Model & $Y$ & Model & $Y$ & Model & $\gamma$ & Model & $Y$ & Model & $\gamma$ & Model & $N$ & Model & $\gamma$ & Model & $Y$ & Model & $\gamma$ & Model & $\gamma$ \\
\hline Q.23 & $Y$ & $Q 24$ & $Y$ & Q25 & $Y$ & Q.26 & $\gamma$ & Q27 & $\gamma$ & Q28 & $Y$ & 0.29 & $N$ & Q30 & $\gamma$ & Q31 & $\gamma$ & Q32 & $\gamma$ & Q33 & $Y$ \\
\hline Q36 & $\mathrm{N}$ & Q36 & $Y$ & Q36 & $\mathrm{N}$ & Q36 & $\mathrm{N}$ & Q36 & N & Q36 & $\mathrm{N}$ & Q36 & $\mathrm{N}$ & Q36 & $\mathrm{N}$ & Q36 & $\mathrm{N}$ & Q36 & N & Q36 & N \\
\hline
\end{tabular}

Table 6: Performance a-Sales growth for the past 5 years.

Where:

$\mathrm{Y}$ means $(\mathrm{P}<=0.05)$ - The effect of the model (variable) is significant

$\mathrm{N}$ means $(\mathrm{P}>0.05)$ - The effect of the model (variable) is NOT significant

For a list of all the $\mathrm{P}$ values see Appendix C. A conclusion from the statistical analysis is summarized in Appendix D. Based on this we were able to say identify among the dependable variables which have a significant effect on the Performance criteria. The overall Information of the analysis is shown in Appendix E. The number of valid models with Independent Q1-Q33 is shown in Appendix F. We found here that most of the planning practices have significant effect on the model except Q3, Q8, Q10. This suggests that the fact that the planning is provided by the president or CEO is not of vital importance. This supports previous research that the engagement of top management is not a prerequisite for strategic planning. More surprising is the results that the regularity of these activities is not of importance. And its' success does not seem 
to depend on earmarked funds for strategic analysis and planning. When we look at the Number of valid independent variables Q1-Q33 (Appendix G), we see that Q2, Q4, Q5, Q7, Q14, Q15-Q23, Q25-Q33 have more significant $\mathrm{P}$ values on the model. We then conclude that:

H3. Certain planning practices have a more significant effect on the performance model

The Hypothesis is accepted. For the fourth hypothesis:

H4. Competitive Intelligence practices have a significant effect on performance.

We recall that Q16-20 got a XX mark for strongly relevant to CI practices. So did Q26-28 and Q31. The average score for these questions were $(10+11+13+12+12+12+9+11+12+9) \quad 11,1$. This suggests that CI practices have a significant effect on performance. The Hypothesis is accepted. For the last hypothesis:

H5. Competitive Intelligence practices have a higher significant effect on performance than other planning activities

\section{References}

Ansoff, H.I. (1965), Corporate Strategy, McGrawHill, New York, NY.

Ansoff, H.I., Avner, J., Brandenburg, R.G., Portner, F.E. and Radosevich, R. (1970), "Does planning pay? The effect of planning on success of acquisitions in American firms", Long Range Planning, Vol. 3, pp. 1-7.

Ansoff, H.I., Declerck, R.P. and Hayes, R.L. (1976), From Strategic Planning to Strategic, Management, John Wiley and Sons, New York, NY.

Ackoff, R.L. (1970), A Concept of Corporate Planning, John Wiley and Sons, New York, NY.

Andersen, T.J. (2000), "Strategic planning, autonomous actions and corporate performance", Long Range Planning, Vol. 33, pp. 184-200.

Aragon-Sanchez \& Sanchez-Marin (2005), J of Small Business managemnt 43 (3), pp 287-308

Armstrong, J.S. (1982), "The value of formal planning for strategic decisions: review of
If we take out Q3 as an out-layer the average for the whole set is 8,9 . This suggests that $\mathrm{CI}$ activities are the more relevant part of Strategic Planning when it comes to its effect on Company Performance, even though the difference is not substantial. The Hypothesis is accepted.

\section{Findings}

Our findings support a large part of previous research done on Strategic Planning and Company Performance. Strategic Planning does have a considerable impact on Company Performance. Moreover, it confirms that Chinese companies seem to follow the same model as western companies.

Whether or not our findings about the Competitive Intelligence function is the same for Western companies is still to be researched. Furthermore, we have tested only one side to CI. It would also be of value if other studies could look at the use of the different stages of the Intelligence Cycle and Company Performance. In today's world where ever more Information Technology is used it would also be interesting to know if there is a relationship between the use of Business Intelligence (software) and Company Performance.

empirical research", Strategic Management Journal, Vol. 3 No. 3, pp. 197-211.

Boyd, K.B. (1991), "Strategic planning and financial performance: a meta-analytic review", Journal of Management Studies, Vol. 28, pp. 353-74.

Brody, R. (2008). Issues in defining competitive intelligence: an exploration. IEEE Engineering Management Review, vol. 36, nr 3, p. 3

Chandler, A. D. Jr., (1962). Strategy and Structure: Chapters in the History of the American Industrial Enterprise. Massachusetts, MIT Press.

Child, J. (1972). Organizational Structure, environment and performance -The role of Strategic Choice. Sociology, Vol. 6, pp. 1-22.

Falshaw, J, Richard, Glaister, Keith W. and Tatoglu, Ekrem (2006). Evidence on formal strategic planning and company performance. Management Decision, Vol. 44 No. 1, pp. 9-30

Falshaw, Llaister, Tatoglu, (2006), Management Decision Vol 44, 1.

Greenley, G.E. (1994), Strategic planning and company performance: An appraisal of the 
empirical evidence Scandinavian Journal of Management, vol 10, No 4, pp. 383-396.

Greenley, G.E. (1986), Does strategic planning improve company performance? Vol. 19, No 2, pp 101-109.

Hambrick, D.C. (1981), Environment, strategy and Power within top management teams. Administrative Science Quarterly, vol. 26, pp. 253-276.

Hambrick, D.C. (1980), "Operationalizing the concept of business-kevel strategy in research", Academy of Management Journal, vol. 5, pp. 567-75.

James, W. and Hatten, K. (1995). Further evidence of the validity of the self-typing paragraph approach: Miles and Snow strategic archetypes in banking. Strategic management journal, vol. 16 (2), pp. 161-168.

Learned, E.P., Christensen, C.R., Andrews, K.R. and Guth, W.D. (1965), Business Policy: Text and Cases, Irwin, Burr Ridge, IL.

Matsuno \& Mentzer (2000), Journal of marketing Oct 2000, 64, 4: pp. 1-16.

Miller, C.C. and Cardinal, L.B. (1994), "Strategic planning and firm performance: a synthesis of more than two decades", Academy of Management Journal, vol. 37, pp. 1649-65.

Miles, R.E. and Snow, C. (1978) Organizational Strategy, Structure and Process, New York, McGraw Hill.

Mintzberg, H. (1979), The Structuring of Organizations, Prentice Hall, Englewood Cliffs, NJ.

Mintzberg, H. (1994), The Rise and Fall of Strategic Planning, Prentice Hall, Hemel Hempstead.

Mintzberg, H. and McHugh, A. (1985), "Strategy formation in an adhocracy", Administrative Science Quarterly, Vol. 30, pp. 160-97.

Mintzberg, H. and Waters, J.A. (1982), "Tracking strategy in an entrepreneurial firm", Academy of Management Journal, vol. 25, pp. 465-99.

Mintzberg, H. and Lampel, J. (1999), "Reflecting on the strategy process", Sloan Management Review, vol. 40 No. 3, pp. 21-30.

Paul L. Dishman, Jonathan L. Calof (2008), Competitive intelligence: a multiphasic precedent to marketing strategy, European
Journal of Marketing, vol. 42, Iss 7/8, pp. $766-$ 785.

Pearce, J.A. II, Freeman, E.B. and Robinson, R.B. $\operatorname{Jr}(1987)$, "The tenuous link between formal strategic planning and financial performance", Academy of Management Review, vol. 12 No. 4, pp. 658-75.

Pleshko \& Nickerson, (2006), proceedings Academey of Strategic Management, vol 4, Number 2, pp 27-31.

Porter, M. (1980). Competitive Strategy; techniques for analyzing Industries and Competitors. New York: The Free Press.

Porter, M. (1987), "Corporate strategy: the state of strategic thinking", The Economist, May 23, pp 21-8.

Ruud, John M., Greenley, Gordon E., Beatson, Amanda T., and Lings, Ian N. (2008), Strategic planning and performance: Extending the debate, Journal of Business Research, 61, 2, pp. 99-109.

Segev, E. (1987). Strategy, strategy making and performance - an empirical investigation. Management Science, vol. 33, pp. 258-267.

Tianjiao Qiu (2008). Scanning for competitive intelligence: a managerial perspective, European Journal of Marketing, vol. 42, Iss. 7/8, pp. 814 835.

Shrader, C.B., Taylor, L. and Dalton, D.R. (1984), "Strategic planning and organizational performance: a critical appraisal", Journal of Management, vol. 10, No. 2, pp. 149-71.

Steiner, G.A. (Ed.) (1963), Managerial Long-Range Planning, McGraw-Hill, New York, NY.

Steiner, G.A. (1979), Strategic Planning, The Free Press, Glencoe, IL.

Steiner, G.A. and Cannon, W.M. (1966), Multinational Corporate Planning, Macmillan,

Varadarajan, P.R. and Ramanujam, V. (1990), "The corporate performance conundrum: a synthesis of contemporary views and an extension", Journal of Management Studies, vol. 27 No. 5, pp. 463-83.

Veliyath, R. and Shortell, S.M. (1993), "Strategic orientation, strategic planning system characteristics and performance", Journal of Management Studies, vol. 30 No. 3, pp. 359-81. 


\section{Appendixes}

\begin{tabular}{|l|l|}
\hline a & Sales growth for the past 5 years \\
\hline b & Average return of equity for the past 3 years \\
\hline c & Ability to gain market share \\
\hline d & Achieve low cost production \\
\hline e & Quality of your management \\
\hline f & Quality of your products or services \\
\hline g & Innovationess/new products \& services \\
\hline h & Stability of profits \\
\hline i & Ability to attract, develop and keep talented manpower \\
\hline j & Record of avoiding major mistakes \\
\hline k & Social responsibility \\
\hline l & Productivity \\
\hline How would your competitors rate your overall performance relative to the \\
\hline
\end{tabular}

Appendix A: Performance Criteria

\begin{tabular}{|l|l|l|}
\hline $\begin{array}{l}\text { Question } \\
\text { uumber }\end{array}$ & Questions asked & $\begin{array}{l}\text { Competitive } \\
\text { Intelligence } \\
\text { indicators }\end{array}$ \\
\hline 1 & $\begin{array}{l}\text { To what extent do top executives support a formal strategic business planning } \\
\text { process? }(0-100 \% \text { optimal) }\end{array}$ & $\mathrm{x}$ \\
\hline 2 & $\begin{array}{l}\text { To what extent is there a clear idea of this organization's strategy that was set some } \\
\text { time ago and has changed very little? }(0-100 \% \text { optimal })\end{array}$ & $\mathrm{x}$ \\
\hline 3 & $\begin{array}{l}\text { To what extent is the strategy of your organization primarily provided by the } \\
\text { president/chief executive and a few of his executives? }(0-100 \% \text { optimal) }\end{array}$ & 0 \\
\hline 4 & $\begin{array}{l}\text { To what extent is your organization continually adapting by making appropriate } \\
\text { changes in its strategy based upon feedback from the marketplace }(0-100 \% \\
\text { optimal })\end{array}$ & $\mathrm{x}$ \\
\hline 5 & $\begin{array}{l}\text { To what extent is there a set of clear and consistent values of this organization that } \\
\text { governs the way you do business? }(0-100 \% \text { optimal })\end{array}$ & 0 \\
\hline 6 & $\begin{array}{l}\text { To what extent is long-term potential valued over short-term performance? (0- } \\
100 \% \text { optimal) }\end{array}$ & $\mathrm{x}$ \\
\hline 7 & $\begin{array}{l}\text { To what extent is the way you do things in this organization well suited to the } \\
\text { business you are in? }(0-100 \% \text { optimal) }\end{array}$ & 0 \\
\hline 8 & \begin{tabular}{l} 
To what extent is strategic dialogue a top priority activity, performed on a regular \\
\hline
\end{tabular} & $\mathrm{x}$ \\
\hline
\end{tabular}




\begin{tabular}{|c|c|c|}
\hline & basis, e.g., each year? (0-100\% optimal) & \\
\hline 9 & $\begin{array}{l}\text { To what extent does the president/chief executive of this organization insists on } \\
\text { placing his mark on virtually every major initiative? (0-100\% optimal) }\end{array}$ & 0 \\
\hline 10 & $\begin{array}{l}\text { To what extent does the organization provide resources (managers' time, money, } \\
\text { staff support, etc.) earmarked specifically for strategic analysis \& planning? (0- } \\
100 \% \text { optimal) }\end{array}$ & $\mathrm{x}$ \\
\hline 11 & $\begin{array}{l}\text { To what extent does the organization follow a defined set of procedures in its } \\
\text { strategic planning process? }(0-100 \% \text { optimal })\end{array}$ & $\mathrm{x}$ \\
\hline 12 & $\begin{array}{l}\text { To what extent do all managers, whose work might be affected significantly by } \\
\text { strategic issues, participate in the planning process? ( } 0-100 \% \text { optimal })\end{array}$ & $\mathrm{x}$ \\
\hline 13 & $\begin{array}{l}\text { To what extent does the organization have a written and well communicated } \\
\text { mission statement? (0-100\% optimal) }\end{array}$ & 0 \\
\hline 14 & $\begin{array}{l}\text { To what extent are all managers and higher-level staff aware of the mission and } \\
\text { understand it? (0-100\% optimal) }\end{array}$ & 0 \\
\hline 15 & $\begin{array}{l}\text { To what extent does the organization systematically measure actual performance } \\
\text { vs. goals? (0-100\% optimal) }\end{array}$ & $\mathrm{X}$ \\
\hline 16 & $\begin{array}{l}\text { To what extent does the organization systematically gather and analyze data about } \\
\text { market and other external factors which affect the business? (0-100\% optimal) }\end{array}$ & $\mathrm{XX}$ \\
\hline 17 & $\begin{array}{l}\text { To what extent do managers evaluate the organization's performance and } \\
\text { operational characteristics systematically compared with those of competitors? ( } 0 \text { - } \\
100 \% \text { optimal) }\end{array}$ & $\mathrm{XX}$ \\
\hline 18 & $\begin{array}{l}\text { To what extent does the organization systematically assess the industry as a whole } \\
\text { in terms of new competitors and concepts, new technologies, procurement } \\
\text { practices, price trends, labor practices, etc.? }(0-100 \% \text { optimal })\end{array}$ & $\mathrm{XX}$ \\
\hline 19 & $\begin{array}{l}\text { To what extent does the organization have knowledge of and access to sources of } \\
\text { information about the industry, markets, and other external factors? }(0-100 \% \\
\text { optimal) }\end{array}$ & $\mathrm{XX}$ \\
\hline 20 & $\begin{array}{l}\text { To what extent does systematic internal analysis identify key strengths and } \\
\text { weaknesses in the organization? (0-100\% optimal) }\end{array}$ & $\mathrm{XX}$ \\
\hline 21 & $\begin{array}{l}\text { To what extent does systematic internal analysis include profitability factor trends, } \\
\text { e.g., after- tax earnings, return on assets, cash flow? (0-100\% optimal) }\end{array}$ & $\mathrm{X}$ \\
\hline 22 & Question withdrawn as it may have been misunderstood & \\
\hline 23 & $\begin{array}{l}\text { To what extent does systematic internal analysis include pricing strategy and its } \\
\text { effects on customer behavior? (0-100\% optimal) }\end{array}$ & $\mathrm{X}$ \\
\hline 24 & $\begin{array}{l}\text { To what extent does systematic internal analysis include quality of customer } \\
\text { service and customer satisfaction/ loyalty/ defection data? (0-100\% optimal) }\end{array}$ & $X$ \\
\hline 25 & $\begin{array}{l}\text { To what extent does systematic internal analysis of the organization assess its } \\
\text { human resource development and management programs? (0-100\% optimal) }\end{array}$ & $X$ \\
\hline 26 & $\begin{array}{l}\text { To what extent does the organization's management information system provide } \\
\text { relatively easy access to the internal data discussed above? (0-100\% optimal) }\end{array}$ & $\mathrm{XX}$ \\
\hline 27 & $\begin{array}{l}\text { After completing its external and internal analyses, to what extent does the } \\
\text { organization review the mission and goals in light of the apparent threats/ } \\
\text { opportunities and strengths/ weaknesses? (0-100\% optimal) }\end{array}$ & $\mathrm{XX}$ \\
\hline 28 & $\begin{array}{l}\text { To what extent does the organization make strategic decisions (implementation } \\
\text { action plans) based upon the strategic plan? }\end{array}$ & $\mathrm{XX}$ \\
\hline 29 & $\begin{array}{l}\text { To what extent does the organization clearly assign lead responsibility for action } \\
\text { plan implementation to a person or, alternately, to a team? (0-100\% optimal) }\end{array}$ & 0 \\
\hline 30 & $\begin{array}{l}\text { To what extent does the organization set clearly defined and measurable } \\
\text { performance standards for each plan element? (0-100\% optimal) }\end{array}$ & $X$ \\
\hline 31 & $\begin{array}{l}\text { To what extent does the organization develop an organized system for monitoring } \\
\text { how well those performance standards were met? (0-100\% optimal) }\end{array}$ & $\mathrm{XX}$ \\
\hline 32 & $\begin{array}{l}\text { To what extent are individuals responsible for strategic planning and } \\
\text { implementation rewarded for successful performance? (0-100\% optimal) }\end{array}$ & $X$ \\
\hline 33 & Question withdrawn as it may have been misunderstood & \\
\hline
\end{tabular}

Appendix B: Questions asked on strategic planning 


\begin{tabular}{|c|c|c|c|c|c|c|c|c|c|c|}
\hline $\begin{array}{c}\text { independ } \\
\text { ent }\end{array}$ & \begin{tabular}{|c|} 
depe \\
ndent
\end{tabular} & $\begin{array}{l}\text { F value } \\
\text { (Model) }\end{array}$ & $\begin{array}{l}\text { P value } \\
\text { (Model) }\end{array}$ & $\begin{array}{c}\text { Rsquare } \\
\text { Model }\end{array}$ & $\begin{array}{l}\text { Fvi } \\
\text { (Q1- }\end{array}$ & $\begin{array}{l}\text { llue } \\
\text { Q33) }\end{array}$ & & $\begin{array}{l}\text { alue } \\
-Q 33)\end{array}$ & $\begin{array}{c}\text { Fvalue } \\
\text { Q36 }\end{array}$ & $\begin{array}{c}\text { P value } \\
\text { Q36 }\end{array}$ \\
\hline Q1,Q36 & $a$ & 2.03 & 0.011 & 0.133834 & Q1 & 1.61 & Q1 & 0.0828 & 3.37 & 0.0105 \\
\hline Q2,Q36 & a & 2.3 & 0.0015 & 0.180489 & $\mathrm{Q} 2$ & 2.44 & $\mathrm{Q2}$ & 0.0017 & 1.7 & 0.1509 \\
\hline Q3,Q36 & a & 1.51 & 0.0679 & 0.13824 & Q3 & 1.14 & Q3 & 0.3087 & 3.27 & 0.0126 \\
\hline Q4,Q36 & a & 2.52 & 0.0006 & 0.186096 & Q4 & 2.43 & Q4 & 0.0022 & 2.87 & 0.024 \\
\hline Q5,Q36 & $a$ & 42 & 0.0008 & 0.188062 & Q5 & 2.7 & Q5 & 0.0005 & 1.2 & 0.3131 \\
\hline Q6,Q36 & a & 1.58 & 0.0594 & 0.125506 & Q6 & 1.34 & Q6 & 0.1772 & 2.55 & 0.0401 \\
\hline Q7,Q36 & $a$ & 2.79 & 0.0001 & 0.203337 & $Q 7$ & 3.07 & $Q 7$ & 0.0001 & 1.68 & 0.1556 \\
\hline Q8,Q36 & a & & 0.0161 & 0.145518 & Q8 & 1.68 & Q8 & 0.0523 & 2.61 & 0.0365 \\
\hline Q9,Q36 & a & 1.82 & 0.0182 & 142 & Q9 & 1.32 & $Q 9$ & 0.1824 & 3.95 & 0.0041 \\
\hline Q10,Q36 & a & 1.84 & 0.0161 & 0.152071 & Q10 & 1.5 & Q10 & 0.0954 & 3.3 & 0.012 \\
\hline Q11,Q36 & a & 1 & 0.4687 & 0.091461 & Q11 & 0.47 & Q11 & 0.9692 & 3.38 & 0.0104 \\
\hline Q36 & $a$ & 1.27 & 0.1905 & 109 & Q12 & 0.88 & Q12 & 0.6021 & 3.1 & 0.0166 \\
\hline 236 & a & 1.24 & 0.2224 & 116 & Q13 & 0.91 & Q13 & 0.5628 & 2.58 & 0.0381 \\
\hline Q14,Q36 & $a$ & 2.4 & 0.0009 & 092 & Q14 & 2.16 & Q14 & 0.0061 & 3.42 & 0.0098 \\
\hline Q15,Q36 & a & 2.22 & 0.0023 & 0.17 & Q15 & 2.18 & Q15 & 0.0056 & 2.39 & 0.0521 \\
\hline Q16, & a & & $<.0001$ & 3074 & Q16 & 3.76 & Q16 & $<.0001$ & 1.03 & 0.3902 \\
\hline 236 & a & & 0.0002 & 78 & Q17 & 3.04 & Q17 & 0.0001 & 1.57 & 0.1828 \\
\hline Q18,Q36 & $a$ & 1.94 & 0.0114 & 629 & Q18 & 1.87 & Q18 & 0.0246 & 2.21 & 0.0694 \\
\hline Q19,Q36 & $a$ & 1.71 & 0.0263 & 0.15348 & Q19 & 1.77 & Q19 & 0.0281 & 1.45 & 0.2201 \\
\hline Q20,Q36 & a & 2.72 & 0.0001 & 582 & $\mathrm{Q} 20$ & 2.69 & Q20 & 0.0004 & 2.87 & 0.024 \\
\hline Q21,Q36 & $a$ & & 0.0014 & 5541 & Q21 & 2.4 & Q21 & 0.0024 & 2.1 & 0.0818 \\
\hline & a & & 0.0257 & & $\mathrm{Q} 22$ & 1.58 & Q22 & 0.0657 & 2.39 & 0.0519 \\
\hline Q23,Q36 & a & 1.85 & 0.0132 & 0.163585 & $\mathrm{Q} 23$ & 1.9 & Q23 & 0.0153 & 1.58 & 0.1794 \\
\hline Q24,Q36 & a & 2.15 & 0.0025 & 0.185471 & $\mathrm{Q} 24$ & 2.04 & Q24 & 0.0078 & 2.65 & 0.0343 \\
\hline Q25,Q36 & a & 2.93 & $<.0001$ & 0.211097 & Q25 & 3.16 & Q25 & $<.0001$ & 2.03 & 0.0916 \\
\hline Q26,Q36 & $a$ & & 0.0089 & 8383 & Q26 & 1.92 & Q26 & 0.0176 & 2.14 & 0.0764 \\
\hline Q27,Q36 & a & 2.42 & 0.0008 & 0.188741 & $Q 27$ & 2.43 & Q27 & 0.0017 & 2.34 & 0.0564 \\
\hline Q28,Q36 & $a$ & 2.29 & 0.0019 & 0.172006 & Q28 & 2.3 & Q28 & 0.0039 & 2.24 & 0.0656 \\
\hline Q29,Q36 & a & 1.51 & 0.0768 & 0.126252 & Q29 & 1.58 & Q29 & 0.0715 & 1.2 & 0.3106 \\
\hline Q30,Q36 & a & 2.62 & 0.0003 & 0.192549 & Q30 & 2.9 & Q30 & 0.0002 & 1.5 & 0.2039 \\
\hline Q31,Q36 & a & 1.83 & 0.0171 & 0.149371 & Q31 & 1.75 & Q31 & 0.0363 & 2.18 & 0.0718 \\
\hline Q32,Q36 & $a$ & 2.7 & 5.0001 & 0.230803 & Q32 & 3 & Q32 & 5.0001 & 1.22 & 0.3039 \\
\hline Q33,Q36 & a & 1.86 & 0.0132 & 0.158349 & Q33 & 1.76 & Q33 & 0.0323 & 2.36 & 0.0548 \\
\hline
\end{tabular}

Appendix $C: F$ values

\begin{tabular}{|l|l|l|}
\hline $\begin{array}{l}\text { Question } \\
\mathrm{nr}\end{array}$ & Measure & Results \\
\hline $\mathrm{a}$ & Sales growth for the past 5 years & $\begin{array}{l}\text { A clear strategy and value, good internal and external } \\
\text { analysis, transparent responsibility among the organization } \\
\text { members and clear performance measurement will increase } \\
\text { the sales growth of the organization. } \\
\text { The strategy planning process seems to have no significant } \\
\text { effect on the sales growth. }\end{array}$ \\
\hline b & $\begin{array}{l}\text { Average return of equity for the past } \\
3 \text { years }\end{array}$ & $\begin{array}{l}(\ldots) \text { will increase the return of equity. } \\
(\ldots) \text { no significant effect on the return of equity. }\end{array}$ \\
\hline c & Ability to gain market share & $\begin{array}{l}(\ldots) \text { will increase the ability to gain market share. } \\
(\ldots) \text { no significant effect on the ability to gain market } \\
\text { share. }\end{array}$ \\
\hline d & Achieve low cost production & $\begin{array}{l}(\ldots) \text { will achieve low cost production. } \\
(\ldots) \text { no significant effect on the achieve low cost } \\
\text { production. } \\
\text { Marketing and advertising can't help the organization to }\end{array}$ \\
\hline
\end{tabular}




\begin{tabular}{|c|c|c|}
\hline & & $\begin{array}{l}\text { achieve low cost production. } \\
\text { Different type of companies have significant difference on } \\
\text { achieving low cost production. }\end{array}$ \\
\hline $\mathrm{e}$ & Quality of your management & $\begin{array}{l}\text { (...) will increase quality of your management. } \\
\text { Different type of companies have significant difference on } \\
\text { quality of management. }\end{array}$ \\
\hline$f$ & Quality of your products or services & $\begin{array}{l}\text { (...) will increase quality of your products or services. } \\
\text { Doing things well suited to the business, this factor do not } \\
\text { play significant effect on increasing the quality of your } \\
\text { products or services. This may give us a hint that all the } \\
\text { business follows the same principle. }\end{array}$ \\
\hline $\mathrm{g}$ & $\begin{array}{l}\text { Innovationess/new products \& } \\
\text { services }\end{array}$ & $\begin{array}{l}\text { (...) will enhance innovation. } \\
\text { Internal analysis does not have significant effect on } \\
\text { innovation. } \\
\text { Different type of companies have significant effect on } \\
\text { innovation. }\end{array}$ \\
\hline $\mathrm{H}$ & Stability of profits & (...) have significant effect on the stability of profits. \\
\hline I & $\begin{array}{l}\text { Ability to attract, develop and keep } \\
\text { talented manpower }\end{array}$ & $\begin{array}{l}\text { (...) have significant effect on the ability to attract, develop } \\
\text { and keep talented manpower. } \\
\text { A defined set of procedures in its strategic planning process, } \\
\text { knowing your customer those factors may have no } \\
\text { significant effect on your ability to attract, develop and keep } \\
\text { talented manpower. }\end{array}$ \\
\hline $\mathrm{J}$ & Record of avoiding major mistakes & $\begin{array}{l}\text { (...) have significant effect on avoiding major mistakes. } \\
\text { Top executives' strategy decision may have no effect on } \\
\text { avoiding major mistakes. }\end{array}$ \\
\hline $\mathrm{K}$ & Social responsibility & $\begin{array}{l}\text { (...) have significant effect on social responsibility. } \\
\text { Different type of companies have no significant difference } \\
\text { on social responsibility. }\end{array}$ \\
\hline $\mathrm{L}$ & Productivity & (...) will increase productivity. \\
\hline $\mathrm{m}$ & $\begin{array}{l}\text { How would your competitors rate } \\
\text { your overall performance relative to } \\
\text { the rest of the industry }\end{array}$ & $\begin{array}{l}\text { (...) will affect how would your competitors rate your } \\
\text { overall performance relative to the rest of the industry. } \\
\text { The strategy planning process may have no significant } \\
\text { effect on how would your competitors rate your overall } \\
\text { performance relative to the rest of the industry. }\end{array}$ \\
\hline
\end{tabular}

Appendix D: Conclusions from Statistical Analysis 


\begin{tabular}{|c|c|c|c|c|c|c|c|}
\hline \multirow{2}{*}{\multicolumn{2}{|c|}{ Dependent Variable }} & \multicolumn{2}{|c|}{$\begin{array}{l}\text { The model is valid or not. } \\
\text { (There are } 33 \text { models for } \\
\text { each performance variable.) }\end{array}$} & \multicolumn{2}{|l|}{$\begin{array}{c}\text { Independent Variable } \\
\text { (The ones which has significant effect are listed below.) }\end{array}$} & \multicolumn{2}{|c|}{$\begin{array}{c}\text { Independent Variable } \\
036\end{array}$} \\
\hline & & $\begin{array}{l}\text { No. of valid } \\
\text { model }\end{array}$ & $\begin{array}{c}\text { No. of iinvalid } \\
\text { model }\end{array}$ & $01-033$ & No. & $\begin{array}{c}\text { No. of } \\
\text { significicant }\end{array}$ & \begin{tabular}{|c|} 
No. of \\
insignnificant
\end{tabular} \\
\hline a & Sales growth for the past 5 years & 27 & 6 & $02,04,05,07,014-021,023-028,030-033$ & 22 & 13 & 20 \\
\hline b) & $\begin{array}{l}\text { Average return of equity for the past } \\
3 \text { years }\end{array}$ & 28 & 5 & $Q 2,04-07,09,015-032$ & 24 & 12 & 21 \\
\hline$c$ & Ability to gain market share & 16 & 17 & $02,04,05,07,016-022,027,028,030,032$ & 15 & 5 & 27 \\
\hline d & Achieve low cost production & 25 & 8 & $02,04,05,07,017-021,025,027-029,032,033$ & 15 & 33 & 0 \\
\hline $\mathrm{e}$ & Quality of your management & 33 & 0 & Q1, Q2, Q4-08, Q10-0.33 & 31 & 33 & 0 \\
\hline$f$ & Quality of your products or services & 32 & 1 & $01,04-06,08-033$ & 30 & 27 & 6 \\
\hline g & $\begin{array}{l}\text { Innovationessinew products \& } \\
\text { services }\end{array}$ & 31 & 2 & $\begin{array}{l}Q 2,04,08,011,013,015,017-019,026,028, \\
032\end{array}$ & 12 & 33 & 0 \\
\hline h & Stability of profits & 31 & 2 & $\begin{array}{l}Q 1, Q 2, Q 4,05, Q 7, Q 8, Q 10, Q 11,013-023,025, \\
Q 27-032\end{array}$ & 26 & 16 & 17 \\
\hline i & $\begin{array}{l}\text { Ability to attract, develop and keep } \\
\text { talented manpower }\end{array}$ & 31 & 2 & $02,04-06,08,010,012-023,026-033$ & 26 & 14 & 19 \\
\hline $\mathrm{i}$ & Record of avoiding major mistakes & 29 & 4 & $01,02,05,06,011,013-0.033$ & 26 & 11 & 22 \\
\hline k & Social responsibility & 14 & 19 & $\begin{array}{l}01,02,05,08, Q 10,011,013-015,018,020-022, \\
Q 26,027,029-033\end{array}$ & 20 & 0 & 33 \\
\hline 1 & Productivity & 33 & 0 & $02,04-07,09,011,014-033$ & 27 & 17 & 16 \\
\hline & $\begin{array}{l}\text { How would your competitors rate } \\
\text { your overall performance relative to } \\
\text { the rest of the industry }\end{array}$ & 21 & 12 & $\begin{array}{l}02, Q 4, Q 6,07,09,015-022,025,026,028,030, \\
032\end{array}$ & 18 & 13 & 20 \\
\hline
\end{tabular}

Appendix E: Summary of Depended and Independent variable results

No. of valid model with independent Q1-Q33

\begin{tabular}{|l|l|l|l|l|l|}
\hline $\mathrm{Q} 1$ & 11 & $\mathrm{Q} 12$ & 8 & $\mathrm{Q} 23$ & 9 \\
\hline $\mathrm{Q} 2$ & 12 & $\mathrm{Q} 13$ & 8 & $\mathrm{Q} 24$ & 8 \\
\hline $\mathrm{Q} 3$ & 3 & $\mathrm{Q} 14$ & 13 & $\mathrm{Q} 25$ & 11 \\
\hline $\mathrm{Q} 4$ & 11 & $\mathrm{Q} 15$ & 12 & $\mathrm{Q} 26$ & 13 \\
\hline $\mathrm{Q} 5$ & 12 & $\mathrm{Q} 16$ & 11 & $\mathrm{Q} 27$ & 12 \\
\hline $\mathrm{Q} 6$ & 9 & $\mathrm{Q} 17$ & 12 & $\mathrm{Q} 28$ & 12 \\
\hline $\mathrm{Q} 7$ & 11 & $\mathrm{Q} 18$ & 13 & $\mathrm{Q} 29$ & 10 \\
\hline $\mathrm{Q} 8$ & 7 & $\mathrm{Q} 19$ & 12 & $\mathrm{Q} 30$ & 12 \\
\hline $\mathrm{Q} 9$ & 11 & $\mathrm{Q} 20$ & 13 & $\mathrm{Q} 31$ & 10 \\
\hline $\mathrm{Q} 10$ & 7 & $\mathrm{Q} 21$ & 12 & $\mathrm{Q} 32$ & 12 \\
\hline $\mathrm{Q} 11$ & 8 & $\mathrm{Q} 22$ & 11 & $\mathrm{Q} 33$ & 12 \\
\hline
\end{tabular}

Appendix F: The No. of valid model 


\begin{tabular}{|l|l|l|l|l|l|}
\hline \multicolumn{6}{|c|}{ No. of valid independent $\mathrm{Q} 1$-Q33 } \\
\hline $\mathrm{Q} 1$ & 5 & $\mathrm{Q} 12$ & 3 & $\mathrm{Q} 23$ & 8 \\
\hline $\mathrm{Q} 2$ & 11 & $\mathrm{Q} 13$ & 7 & $\mathrm{Q} 24$ & 6 \\
\hline $\mathrm{Q} 3$ & 0 & $\mathrm{Q} 14$ & 8 & $\mathrm{Q} 25$ & 9 \\
\hline $\mathrm{Q} 4$ & 11 & $\mathrm{Q} 15$ & 11 & $\mathrm{Q} 26$ & 9 \\
\hline $\mathrm{Q} 5$ & 11 & $\mathrm{Q} 16$ & 10 & $\mathrm{Q} 27$ & 11 \\
\hline $\mathrm{Q} 6$ & 7 & $\mathrm{Q} 17$ & 11 & $\mathrm{Q} 28$ & 12 \\
\hline $\mathrm{Q} 7$ & 8 & $\mathrm{Q} 18$ & 13 & $\mathrm{Q} 29$ & 9 \\
\hline $\mathrm{Q} 8$ & 5 & $\mathrm{Q} 19$ & 12 & $\mathrm{Q} 30$ & 10 \\
\hline $\mathrm{Q} 9$ & 4 & $\mathrm{Q} 20$ & 12 & $\mathrm{Q} 31$ & 9 \\
\hline $\mathrm{Q} 10$ & 6 & $\mathrm{Q} 21$ & 12 & $\mathrm{Q} 32$ & 13 \\
\hline $\mathrm{Q} 11$ & 6 & $\mathrm{Q} 22$ & 10 & $\mathrm{Q} 33$ & 8 \\
\hline
\end{tabular}

Appendix G: The No. of valid independent variable Q1-Q33 that has significant effect on the models. 